\title{
Females of Tapinotaspoides, a genus in the oil-collecting bee tribe Tapinotaspidini, collect secretions from non-floral trichomes (Hymenoptera, Apidae)
}

\author{
Gabriel A. R. Melo ${ }^{1} \&$ Maria Cristina Gaglianone ${ }^{2}$
}

\begin{abstract}
'Departamento de Zoologia, Universidade Federal do Paraná, Cx. postal 19020, 81531-990 Curitiba-PR, Brazil. garmelo@ufpr.br ${ }^{2}$ Universidade Estadual do Norte Fluminense, Centro de Biociências e Biotecnologia, Laboratório de Ciências Ambientais, Av. Alberto Lamego 2000, 28015-620 Campos dos Goytacazes-RJ, Brazil. mcrisgag@uenf.br
\end{abstract}

\begin{abstract}
Females of Tapinotaspoides, a genus in the oil-collecting bee tribe Tapinotaspidini, collect secretions from non-floral trichomes (Hymenoptera, Apidae). Harvesting of secretions from non-floral trichomes by females of Tapinotaspoides serraticornis is reported for the first time. The females exhibit a type of mopping behavior using the fringes of long, wavy setae along the posterior margins of their metasomal sterna. Our observations indicated a wide range of host plants used as sources for these secretions, including Waltheria (Sterculiaceae), Tibouchina (Melastomataceae), Sida (Malvaceae), Jacquemontia (Convolvulaceae), and unidentified species of Commelinaceae and Cyperaceae.
\end{abstract}

KEYwORDs. Apoidea; foraging behavior; glandular trichomes; Lipids.

Resumo. Fêmeas de Tapinotaspoides, um gênero de abelhas coletoras de óleo da tribo Tapinotaspidini, coletam secreções de tricomas extra-florais (Hymenoptera, Apidae). A coleta de secreções de tricomas não-florais por fêmeas de Tapinotaspoides serraticornis é descrita pela primeira vez. Fêmeas desta espécie realizam um tipo de mopping, com as franjas de cerdas longas e curvas, localizadas nas margens posteriores dos esternos metassomais. Nossas observações indicam a utilização de um amplo espectro de plantas hospedeiras, incluindo espécies de Waltheria (Sterculiaceae), Tibouchina (Melastomataceae), Sida (Malvaceae), Jacquemontia (Convolvulaceae), Commelinaceae e Cyperaceae.

Palavras-Chave. Apoidea; forrageamento; Lipídeos; tricomas glandulares.

Besides pollen and nectar, females in several groups of bees collect floral oils as food for their immatures (e.g. Buchmann 1987; Simpson \& Neff 1981; Vogel 1974). This specialized behavior has evolved at least 4 to 6 times independently among bees: once in the Melittinae s.l. and once in each of the ancestral lineages that gave rise to the apine tribes Tetrapediini, Ctenoplectrini, Centridini and Tapinotaspidini (Michener 2000; Roig-Alsina 1997). As few as three independent origins might exist, since sister group relationships between either Tapinotaspidini and Ctenoplectrini or Tetrapediini and Ctenoplectrini have been suggested by, respectively, Roig-Alsina \& Michener (1993) and Alves-dos-Santos et al. (2002). It has been shown for some of these groups that the females also use the floral oils as nesting material [see Alves-dos-Santos et al. (2002) for Tetrapediini, Buchmann (1987) for Centridini, and Cane et al. (1983) for Macropis. There is also evidence that Ctenoplectra Kirby, 1826 (Rozen 1978) and the wood-nesting Paratetrapedia Moure, 1941 (Tapinotaspidini; Melo unpublished) use oils in nesting construction as well].

Since the first reports by Vogel (1974), production of floral oils as rewards for pollinators is now known to be present in Malpighiaceae, Krameriaceae, Orchidaceae, Solanaceae, Iridaceae, Myrsinaceae, Cucurbitaceae and Scrophulariaceae [whose genera known to have oil-flowers are now placed in three separate families by Olmstead et al. (2001)]. The plant tissue specialized in producing oils, the elaiophores, can be trichomatic or epithelial (Vogel 1974).

The morphological diversity of the structures associated with oil-collecting in the Tapinotaspidini were recently described in detail by Cocucci et al. (2000). Except for Tapinotaspoides Moure, 1944, females of the other eight genera of Tapinotaspidini have the collecting apparattus on their fore and/or mid legs. Females of Tapinotaspoides are unique within Tapinotaspidini for possessing specialized fringes of long, wavy setae along the posterior margins of the metasomal sterna 3, 4 and 5 [see Fig. 13 in Cocucci et al. (2000)]. These setae are shaped as thin, wavy blades with short, spiny projections along their anterior edge. The collected substances most likely accumulate between the tiny spaces formed when adjacent setae come in close contact [see Fig. 13D in Cocucci et al. (2000)]. Although it has been repeatedly suggested that the sternal hair fringes of Tapinotaspoides would be used for mopping floral trichomes (e.g. Neff \& Simpson 1981; Cocucci et al. 2000), no observation of oil-collecting has been previously reported for these bees.

The first clue that Tapinotaspoides might depend on nonfloral rather than floral sources of oily secretions came from a fortuitous observation made by GARM when collecting bees near the town of Jaíba, in the northern, semi-arid region of 
Minas Gerais (southeastern Brazil). On April 09, 1998, a female of T. serraticornis (Friese, 1899) was seen to land and walk downward for about $5 \mathrm{~cm}$ along the stem of a plant of an unidentified species of Waltheria (Sterculiaceae) whose stems and leaves were covered by glandular trichomes producing a sticky secretion smelling of resin. Although the female stayed on the plant for only a few seconds (she was collected immediately after taking flight), her behavior clearly suggested that she could be harvesting secretions from the stem trichomes.

Confirmation that Tapinotaspoides gather secretions from non-floral trichomes came two years later when we were able to repeatedly observe and follow females of $T$. serraticornis on their host plants. Our observations were carried out in an abandoned pasture land in the "Fazenda Rio Grande" $\left(21^{\circ} 12^{\prime}\right.$ S, $47^{\circ} 09^{\prime} \mathrm{W}$ ), a farm near the town of Cajuru, in the State of São Paulo. The area was visited on March 25, 30, April 4 and 15, 2000, and then on April 12-14, 2001. On three of these visits, we observed and tape recorded females foraging for secretions on the plants.

In 2000, the females were observed on two species of Tibouchina (Melastomataceae), T. cfr. herbacea (DC.) Cogn and T. cerastifolia (Naudin) Cogn, and in 2001, we saw them on an unidentified species of Commelinaceae and on Sida urens L. (Malvaceae). At Tibouchina and Sida, the females were seen walking over the plant stems, and more rarely, over leaves and flower buds, while in the Commelinaceae, they visited the inflorescences, in particular those in which the flowers had not opened yet. It should be pointed out that in Tibouchina and Sida, the glandular trichomes were more abundant on the stems and flower buds, particularly on younger shoots; in the Commelinaceae, the glandular trichomes were restricted to the inflorescences.

The females behaved in a similar fashion at all visited plants. They walked on the stems, or inflorescences, dragging their metasoma over the glandular trichomes, either following a straight line or sometimes wiggling the metasoma. Usually, they landed on the upper portion of a stem and walked downward for variable distances, then returned back up the stem again. During the walks and before taking flight, the females frequently scraped their hind legs on the sides of the metasoma. They frequently made short flights when moving between branches of a larger plant or when visiting adjacent plants. It is likely that the spiny projections of the modified sternal setae are involved in the wall rupture of the vesicles of the trichomes, helping expose the secretions. Females captured while walking on the plant trichomes had liquid accumulated in their tibial scopae, indicating that the secretions are really harvested.

The anecdotal data presented above, as well as more recent observations (in 2003) by GARM of females of T. serraticornis on stems of an unidentified Jacquemontia (Convolvulaceae) and on inflorescences of an unidentified Cyperaceae, indicates that this bee species uses a wide range of host plants. Future investigations should analyze the chemical composition of the secretions produced by the visited plants. Also, it is not known how these secretions are used by the bees, if only for cell lining, only as larval food, or both.

This type of non-floral trichome mopping is probably exhibited by all Tapinotaspoides, since females in all seven known species possess the fringes of specialized setae on their sterna (Melo \& Aguiar in preparation). The origin of this behavior and associated morphological structures in Tapinotaspoides remains enigmatic. Roig-Alsina's (1997) phylogeny places Tapinotaspoides as sister-group of Caenonomada. On the other hand, a sister-group relationship between Tapinotaspoides and Tapinotaspis should also be considered. Compared to other Tapinotaspidini, these two genera exhibit similar female leg proportions (Cocucci et al. 2000) and male antennal features (Melo \& Aguiar in preparation). Also, their females are unique within the tribe for lacking an oil-collecting apparatus in the fore legs.

Acknowledgments. To Renato Goldenberg (UFPR) for identification of the Tibouchina.

\section{REFERENCES}

Alves-dos-Santos, I.; G. A. R. Melo \& J. G. Rozen. 2002. Biology and immature stages of the bee tribe Tetrapediini (Hymenoptera: Apidae). American Museum Novitates 3377, 45p.

Buchmann, S. L. 1987. The ecology of oil flowers and their bees. Annual Review of Ecology \& Systematics 18: 343-369.

Cane, J. H.; G. C. Eickwort; F. R. Wesley \& J. Spielholz. 1983. Foraging, grooming and mate-seeking behaviors of Macropis nuda (Hymenoptera, Melittidae) and use of Lysimachia ciliata (Primulaceae) oils in larval provisions and cell linings. American Midland Naturalist 110: 257-264.

Cocucci, A. A.; A. Sércic \& A. Roig-Alsina. 2000. Oil-collecting structures in Tapinotaspidini: their diversity, function and probable origin. Mitteilungen der Münchner Entomologischen Gesellschaft 90: 51-74.

Michener, C. D. 2000. The Bees of the World. Baltimore, John Hopkins University Press, 913 p.

Neff, J. L. \& B. B. Simpson. 1981. Oil-collecting structures in the Anthophoridae (Hymenoptera): morphology, function, and use in systematics. Journal of the Kansas Entomological Society 54: $95-123$.

Olmstead, R. G.; C. W. DePamphilis; A. D. Wolfe; N. D. Young; W. J. Elisons \& P. A. Reeves. 2001. Disintegration of the Scrophulariaceae. American Journal of Botany 88: 348-361.

Roig-Alsina, A. 1997. A generic study of the bees of the tribe Tapinotaspidini, with notes on the evolution of their oil-collecting structures. Mitteilungen der Münchner Entomologischen Gesellschaft 87: 3-21.

Roig-Alsina, A. \& C. D. Michener. 1993. Studies of the phylogeny and classification of long-tongued bees. University of Kansas Science Bulletin 55: 124-162.

Rozen, J. G. 1978. The relationship of the bee subfamily Ctenoplectrinae as revealed by its biology and mature larva. Journal of the Kansas Entomological Society 51: 637-652.

Simpson, B. B. \& J. L. Neff. 1981. Floral rewards: alternatives to pollen and nectar. Annals of the Missouri Botanical Garden 68: $301-322$.

Vogel, S. 1974. Ölblumen und ölsammelnde Bienen. Tropische und Subtropische Pflanzenwelt 7: 1-267. 